\title{
Climate Change/Global Warming and Its Impacts on Parasitology/ Entomology
}

\author{
Ngongeh, Lucas Atehmengo ${ }^{1 *}$, Idika Kalu Idika ${ }^{3}$ and Agbede, Rowland Ibrahim Shehu² \\ ${ }^{1}$ Department of Veterinary Microbiology and Parasitology, College of Veterinary Medicine, Michael Okpara University \\ of Agriculture, Umudike, Abia State, Nigeria \\ ${ }^{2}$ Department of Veterinary Parasitology and Entomology, Faculty of Veterinary Medicine, Ahmadu Bello University \\ ${ }^{3}$ Department of Veterinary Parasitology and Entomology, Faculty of Veterinary Medicine, University of Nigeria, Nsukka
}

\begin{abstract}
Climate change and global warming are important phenomena and do not mean the same thing as is wrongly conceived by some individuals. However, the link between the two is strong and one, global warming is strictly an average increase in the temperature of the atmosphere near the earth's surface and in the troposphere, while the other, climate change is more diverse and refers to any significant change in measures of climate such as temperature, precipitation, or wind lasting for a long period of time usually several years. Climate change could thus be an increase or decrease in temperature. The most important of the two terms which is under spotlight is global warming, an increase in temperature which has been blamed largely to greenhouse effect. There can no longer be any doubt that the earth's climate is changing. It is now obvious that even the most hardened sceptics are starting to waiver in their convictions. Climate has been thrown completely out of kilter and each day brings fresh proof such as frequent and more violent cyclones in the Caribean, floods in Africa, the Philippines, the gradual sinking of Islands in the Pacific, heat waves in Europe and the melting of glaciers. There is increase in global average air and ocean temperatures, widespread melting of snow and rising global average sea level. Impacts of global warming include the emergence and re-emergence of some parasitic infections and diseases.
\end{abstract}

Keywords: Causes, climate change, evidence, global warming, impacts, parasitology/entomology.

\section{INTRODUCTION}

Climate change, particularly global warming is said to be caused mainly by the greenhouse effect, and the resulting increase in global temperatures is causing diseases and vectors to spread to higher altitudes in mountainous regions and to higher latitudes that were previously free of the infections. This is the case with Southern United States and the Mediterranean area to name only two $[1,2]$. Significant global warming due to the greenhouse effect is occurring and is leading to disequilibrium in the physical and biological ecosystems with resultant consequences. Natural climatic changes in the past have occurred over thousands or millions of years. For example, global warming of 5000 to 15000 year ago completely changed the face of the planet. This was however said to be insidious unlike the rapid change which man-made' global-warming' is precipitating.

The potential impact of climatic change on communicable disease patterns is obvious and can be summarized as: (i) modification of vector (usually arthropod)

*Address correspondence to this author at the Department of Veterinary Microbiology and Parasitology, College of Veterinary Medicine, Michael Okpara University of Agriculture, Umudike, Abia State, Nigeria;

Tel: +2348064645442; E-mail: mapalah@ gmail.com ecology, this relates principally to infections currently prevalent in tropical and subtropical regions, (ii) intensification of human-related risk factors including reduced availability and quality of drinking water, cooking and sanitation facilities, extent of irrigation and (iii) an increase in soil, airborne and other diseases, directly related to the socioeconomic consequences of changed human behaviour. Alteration in the pattern of rainfall is a potential impact of climate change in the spread of vector-borne diseases and Gubler et al. [3] have outlined possible mechanisms by which this could occur viz: (i) increased surface water can provide breeding sites for vectors, (ii) low rainfall can also increase breeding sites by slowing river flow, (iii) increased rain can increase vegetation and allow expansion in population of vertebrate host, (iv) flooding may eliminate habitat for both vectors and vertebrate hosts and (v) flooding may force vertebrate hosts into closer contact with humans.

\subsection{Definition of Climate Change and Global Warming}

The terms climate change and global warming are often used as synonyms although they do not actually mean the same thing as would be seen in the following definitions. However, the National Academy of Sciences is of the opinion and rightly so that the phrase 'climate change' is growing 
in preferred use to 'global warming' because it conveys that the fact a change could be an increase or a decrease in temperature.

\subsubsection{Climate Change}

Climate change is defined as any significant change in measures of climate (such as temperature, precipitation, or wind) lasting for a long period of time usually several years. The factors which could lead to climate change vary but include natural factors, such as changes in the sun's intensity, slow changes in the earth's orbit around the sun, natural processes within the climate system (such as changes in ocean circulation) and human activities that change the atmosphere's composition (such as through the burning of fossil fuels) and the land surface (such as deforestation, reforestation, urbanization and desertification) [4]. Climate change is said to be a normal part of the earth's natural variability, which is related to interactions among the atmosphere, ocean, and land, as well as changes in the amount of solar radiation reaching the earth [5]. The geologic record includes significant evidence for large scale climate changes in the past of the earth [5]. Climate change has also been defined as a long-term shift in the statistics of the weather (including its averages). For example, it could show up as a change in climate normals (expected average values for temperature and precipitation) for a given place and time of year, from one decade to the next. The global climate is currently changing. The last decade of the 20th Century and the beginning of the 21 st have been the warmest period in the entire global instrumental temperature record starting in the mid-19th century. Reports of glacial melting, higher altitude melting points and changing species distribution are some evidence of climate change [6].

\subsubsection{Global Warming}

Global warming has been defined as an average increase in the temperature of the atmosphere near the earth's surface and in the troposphere, which can contribute to changes in global climate patterns. Global warming can occur due to a variety of causes which may be natural or human induced. Global warming is commonly used to mean the warming that can occur as a result of increased emissions of green house gases from human activities. Global warming is also defined as the rising average temperature of the earth's atmosphere and oceans since the late 19th century and its projected continuation. Since the early 20th century, the earth's average surface temperature has increased by about $0.8^{\circ} \mathrm{C}\left(1.4^{\circ} \mathrm{F}\right)$, with about two thirds of the increase occurring since 1980 [7]. Warming of the climate system is unequivocal, and scientists are more than $90 \%$ certain that most of it is caused by increasing concentrations of greenhouse gases produced by human activities such as deforestation and the burning of fossil fuel $[4,8]$. These findings are recognized by the national science academies of all major industrialized nations [9].

Due to the importance of climate change, meetings have been held with expanded participants since 1967 after the Nobel Prize-winning chemist Svante Arrhenius first proposed the idea of global warming in 1896 [10]. It was speculated that the continued burning of coal and oil would increase concentrations of carbondioxide in the earth's atmosphere with a resultant warmer climate [10]. In 1987 the Mon- treal Protocol was initiated and went into force in 1989. This protocol was an international treaty aimed at protecting the Ozone layer by phasing out the production of substances believed to be responsible for depletion of Ozone. The Protocol has gone through a series of revisions firstly in 1990, 1991, 1992, 1993, 1995, 1997 and 1999 respectively in London, Nairobi, Copenhagen, Bangkok, Vienna, Montreal and Beijing [11]. The accord is widely adopted internationally and it is believed that at that rate Ozone could recover at 2050 [12]. In 1997 the Kyoto Protocol was adopted in Japan committing members of industrialized countries to cutting greenhouse gas emissions [13]. In 2007 the 13th United Nations Climate change Conference in Bali, Indonesia took place with 180 countries in attendance together with observers of both governmental and nongovernmental organizations [14].

\subsection{An overview of Climate Change/Global Warming and its Effects on Parasitology}

It has been aptly reported by Dobson et al. [15] and Hoberg [16] that climate change will alter biotic and abiotic conditions and destroy ecological barriers thereby redrawing maps of current distribution of parasites and their hosts. Climate change and global warming in particular are eminent and its impacts on parasitology are obvious. The days in which one region could be totally free of some infectious diseases based on its temperature and location seems to be over. For instance, America does not worry about diseases such as elephantiasis because such diseases of the tropics could not thrive in temperate climates [17]. However, this could change soon according to a group of scientists who have examined animal and plant diseases worldwide. They emphasized that global warming are turning the world to a better habitat for parasites. An instant was made of Hawaiian birds, which contracts a form of malaria from mosquitoes. The disease is widespread at low altitudes but until recently the mountains were too cold for the mosquitoes to thrive, a reason for the absence of the disease on the mountains. Unfortunately, the climate warming has pushed warmer air high up making the mountains conducive for the mosquitoes leading to the presence of the disease in the mountain birds.

The changes in climate are beginning to have interesting and potentially dramatic effects on the way infectious diseases affect wildlife. In temperate climates, for example, cold winters are a natural way to kill off a lot of diseases carried by insect or tick vectors. Warmer winters however lead to the survival of more of these vectors and this coupled with the heat stress on animals themselves reduces their ability to cope with the diseases. The effects of global warming, which are now getting more obvious were long predicted, however, ample evidence to support it was lacking. In another example, livestock diseases transmitted by insects in Africa have recently spread to new areas farther from the equator. Shifting patterns of abundance and distribution of pathogens, including metazoan and protozoan parasites, and the emergence of infectious disease in people, livestock and wildlife, are among the most important impacts of climate change [18-23].

Vector-borne diseases are transmitted by arthropods including ticks and various types of mosquitoes and their 
spread is enhanced by rainfall, high humidity and high temperature. Malaria is a serious vector-borne disease caused by Plasmodium species is sadly fast spreading widely due to climate change. People in developing countries are most likely to be affected by the impact of climate change on malaria's expansion. Many of these countries are in ideal geographical locations for the spread of malaria and have poor health infrastructure to cope with the effect of this spread. It is therefore important to improve health networks in developing nations and decrease the effects of global warming to prevent the possibility of devastating effects caused by an increase in malarial transmission. Malaria is spread by bites from female mosquitoes carrying one of four species of the parasite namely Plasmodium falciparum, $P$. vivax, $P$. ovale and $P$. malaria [24] (Kumar and Clark, 2002). Approximately seventy different species of the Anopheles mosquito carry the malaria parasite, including the particularly active Anopheles gambiae in Africa [25]. The Plasmodium parasite develops in the mosquito's gut, depending on whether it is exposed to the appropriate temperature and then passed into bloodstream of the host [24]. Symptoms of malaria include are numerous but the most common ones include headache, vomiting, fever and chills [26] and, if left untreated, can result in serious illness and death [26].

Climate change can also result to increased rainfall which in turn generally favours the transmission of vector-borne diseases by providing more breeding grounds for the vectors. Though decreased rainfall has been linked with epidemics of St Louis encephalitis (SLE) as the breeding of Culex pipiens commences in urban drainage systems [27], heavy rainfall has also been shown to precipitate epidemics of SLE in Florida because heavy rains favour the blood-feeding activities of Culex nigripalpus [28]. In fact the transmission and distribution of a lot of diseases that are transmitted by mosquitoes such as dengue and yellow fever, by sandflies such as leishmaniasis and by ticks such as Lyme disease and tickborne encephalitis would likely be altered by climate change. Warming climates with resultant high temperatures have been shown to increase cercarial output and therefore increase the risk of fasciolosis $[29,30]$.

Cryptosporidium parvum causes great illness via waterborne transmission in both developed and developing countries [31,32]. Infections with Cryptosporidium parvum lead to diarrhoeal diseases particularly in immune-compromised individuals [33]. The prevalence of cryptosporidiosis has been shown to highest during the hot humid weather. In India, Bangladesh and Guatamala the peak prevalence was in the rainy season [34-36].

In the preceding paragraphs it has generally been emphasized that global warming would enhance the development and spread of parasitic infections. However, global warming does not just generally translates to increase parasitism and its consequences as can be seen in the following analysis. Hall et al. [37] had questioned if an increasingly warmer world would necessarily become a sicker world. He argued that an increased in temperature can accelerate the fitness of parasites, reduce recruitment bottlenecks for parasites during winter, and weaken hosts. The researchers further noted that warmer temperatures may allow vectors of parasites to expand their range which would enable them to introduce dis- eases to novel habitats as claimed for malaria by climate alarmists, and that it may not apply to all taxa.

Stacey et al. [38] puts it that virulence of parasites may either not alter, may decrease, or may respond in an undefined manner to increasing temperatures. In this regard they further noted that vital rates increase with hotness until some optimum is reached and that once temperature exceeds this optimum, vital rates decline gradually with increasing temperature for some taxa, but rapidly for others such that in some host-parasite systems, a parasite's optimum occurs at cooler temperatures than the optimum of its host [39-41] on fungus-grasshopper associations. They argued that in such cases, a host can use warmer temperatures to help defeat its parasites through behavioural modification of its thermal environment. Warmer temperatures can also lead to shifts in temperature optima [42-44], and the exact evolutionary trajectory of host-parasite systems in a warmer world may depend sensitively upon underlying genetic correlation structures and interactions between host genotypes, parasite genotypes, and the environment $[38,41,45,46]$ Consequently, the "longr-term response of the physiology of host-parasite systems to global warming becomes difficult to predict."

Predators can inhibit epidemics by selectively culling sick hosts and/or by maintaining host densities below levels required for parasites to persist [46-51] Hall et al. [52] argued that global warming does not necessarily mean that disease prevalence will increase in all systems. Morgan and Wall [53] have reemphasized many of the salient points earlier raised by Hall et al. [52] and further elucidated the complex nature of global warming. It was reported that just as the development rates of many parasites of veterinary importance increase with temperature, so do their mortality rates increase, reiterating the notion that temperature will also affect mortality indirectly through the action of predators, parasitoids, pathogens and competitors, whose development and abundance are also potentially temperature sensitive, and the implication is that the net effect of climate change could be more complex and far from easily predicted [53].

Several biological mechanisms (including increased parasite mortality and more rapid acquisition of immunity) in tandem with changes in husbandry practices (including reproduction, housing, nutrition, breed selection, grazing patterns and other management interventions) might act to mitigate increased parasite development rates, preventing dramatic rises in overall levels of diseases [53]. Wall and Ellse [54] observed that a higher temperature increased strike incidence disproportionately in ewes in early summer, but had relatively less direct effect on the pattern of lamb strike incidence, noting that $" \mathrm{a} 3^{\circ} \mathrm{C}$ increase in average temperature approximately doubles the cumulative incidence of strike in lambs but results in four times more strikes in ewes. The simulations suggest that integrated changes in husbandry practices are likely to be able to manage expected increases in strike, given the range of climate changes currently predicted [55]. Modest changes in husbandry practices should be able to manage expected increases in strike, under the range of climate changes currently predicted, demonstrating that consideration of the likely impact of climate change 
must take into account animal management practices as well as parasite biology [53].

\section{CAUSES OF CLIMATE CHANGE}

The factors which could lead to climate change are numerous and include natural causes such as changes in the sun's intensity or slow changes in the earth's orbit around the sun; natural processes within the climate system (such as changes in ocean circulation); and human activities that alter the atmospheric composition (such as through the burning of fossil fuels) and the land surface (such as deforestation, reforestation, urbanization and desertification) [4,8]. Climate change per se is a normal part of the earth's natural variability, which is related to interactions among the atmosphere, ocean, and land, as well as changes in the amount of solar radiation reaching the earth [5]. Records of geology show great evidence for large-scale climate change of earth in the past [5].

Of all the factors that may contribute to the increasing global warming, greenhouse gas emission is the single most important as $\mathrm{CO}_{2}$ levels in the atmosphere have been shown to be increasing rapidly over time [10]. This is as a result of increased use of fossil fuels although deforestation plays a little role too. Increasing civilization, industrialization and development go hand in glove. Much of the machines are powered with fossil fuels and the resultant effect of this is the emission of high amounts of $\mathrm{CO}_{2}$ to the atmosphere. This in turn raises the surrounding temperatures. Therefore, until cleaner sources of energy, that is, $\mathrm{CO}_{2}$-free energy are discovered and used, curtail of global warming will remain farfetched because the burning of fossil fuel is a positivefeedback mechanism. The fossil fuel on the one hand provides the much needed energy to run machines but at the same time the machines releases $\mathrm{CO}_{2}$ to the atmosphere. On the other hand cutting down fossil fuel consumption implies either not operating or reduced operation of machines and the consequence is low industrial output and resultant low gross domestic product of some nations, hence the hesitation of some great industrialized countries to cut down their gas emissions.

\subsection{Greenhouse Gases from the Burning of Fossil Fuels}

Certain naturally occurring gases, such as carbon dioxide $\left(\mathrm{CO}_{2}\right)$ and water vapour $\left(\mathrm{H}_{2} \mathrm{O}\right)$ trap heat in the atmosphere causing a greenhouse effect. Burning of fossil fuels, like oil, coal, and natural gas adds $\mathrm{CO}_{2}$ to the atmosphere. The present level of $\mathrm{CO}_{2}$ in the atmosphere is the highest in the past 650,000 years. The Fourth Assessment Report of the Intergovernmental Panel on Climate Change (IPCC) stated that most of the observed increase in the globally averaged temperature since the mid $-20^{\text {th }}$ century is certainly due to the increase in anthropogenic greenhouse gas concentrations $[8,55]$.

The greenhouse effect is the process by which absorption and emission of infrared radiation by gases in the atmosphere warms a planet's lower atmosphere and surface. It was proposed by Joseph Fourier in 1824 and was first investigated quantitatively by Svante Arrhenius in 1896 [56]. Naturally occurring amounts of greenhouse gases have a mean warming effect of about $33{ }^{\circ} \mathrm{C}$ [57]. The major greenhouse gases are water vapor, which causes $36-70 \%$ of the greenhouse effect; carbon dioxide $\left(\mathrm{CO}_{2}\right)$, which causes 9-26\%; methane $\left(\mathrm{CH}_{4}\right)$, which causes 4-9\%; and ozone $\left(\mathrm{O}_{3}\right)$, which causes 3$7 \%$ [58-60]. Clouds also affect the radiation balance through cloud forcings similar to greenhouse gases.

Human activity since the Industrial Revolution has increased the amount of greenhouse gases in the atmosphere, leading to increased radiative forcing from $\mathrm{CO}_{2}$, methane, tropospheric ozone, CFCs and nitrous oxide. The concentrations of $\mathrm{CO}_{2}$ and methane have increased by $36 \%$ and $148 \%$ respectively since 1750 [61]. These concentrations are said to be much higher than at any time during the last 800,000 years, the period for which reliable data has been extracted from ice cores [62]. Less direct geological evidence indicates that $\mathrm{CO}_{2}$ values higher than this were last seen about 20 million years ago [63]. Fossil fuel burning has produced about three-quarters of the increase in $\mathrm{CO}_{2}$ from human activity over the past 20 years. The rest of the increase in the concentration levels of $\mathrm{CO}_{2}$ is caused mostly by changes in land-use, particularly deforestation [64].

Scientists have generally concluded that human activity is the root cause of increasing global temperature and this is mainly as a result of burning fossil fuels with smaller contribution from deforestation [10]. The impact of $\mathrm{CO}_{2}$ on global warming remains very significant as its atmospheric concentration is rapidly increasing as the years go by.

\subsection{Solar Activity}

Solar variations causing changes in solar radiation energy reaching the earth have been the cause of past climate changes [65]. The effect of changes in solar forcing in recent decades is uncertain, but small, with some studies showing a slight cooling effect [66] while other studies suggest a slight warming effect [67].

\section{INDICATORS OF CLIMATE CHANGE}

There can no longer be any doubt that the earth's climate is changing. It is now obvious that even the most hardened sceptics are starting to waiver in their convictions. Yes, the climate has been thrown completely out of kilter and each day brings fresh proof such as frequent and more violent cyclones in the Caribean, floods in Africa, the Philippines, the gradual sinking of Islands in the Pacific, heat waves in Europe and the melting of glaciers. More evidence to enhance the appreciation of climate change include increases in global average air and ocean temperatures, widespread melting of snow and rising global average sea level [8,68, 69]. For instance the earth's average surface temperature expressed as a linear trend rose by $0.74 \pm 0.18{ }^{\circ} \mathrm{C}$ over the period 1906-2005 [8,68,69].

\section{IMPACTS OF CLIMATE CHANGE/WARMING ON PARASITES AND PARASITIC DISEASES}

The resultant effects of global warming include the emergence and re-emergence of some parasitic infections and diseases [70,71]. A good example is presented by the fact that livestock diseases transmitted by insect vectors in Africa have recently spread to new areas farther from the equator and shifting patterns of abundance and distribution 
of pathogens, including metazoan and protozoan parasites, and the emergence of infectious diseases in people, livestock and wildlife, as among the most important impacts of climate change [18-23]. Involvement of global warming on infectious/communicable diseases can be summarized as modification of vector (usually arthropod) ecology and this relates principally to infections currently prevalent in tropical and subtropical regions, intensification of human-related risk factors including reduced availability and quality of drinking water, cooking and sanitation facilities and extent of irrigation to name a few, and an increase in soil, airborne and other diseases, directly related to the socioeconomic consequences of changed human behaviour.

Global warming has been detected in both the natural and ecological systems.

\subsection{Global Warming in Natural Systems}

The rising sea levels and decreases in snow and ice extent are consistent with warming [8]. Most of the increase in global average temperature since the mid-20th century is attributable to human-induced changes in greenhouse gas concentrations [55]. Global emissions are likely to continue to increase in spite of the policies designed to mitigate the emissions [72]. Partial deglaciation of the Greenland ice sheet, and to an extent the West Antarctic ice sheet, could contribute 4-6 mor more to sea level rise [8]. Changes in regional climates are expected to include greater warming over land, with most warming at high northern latitudes, and least warming over the Southern Ocean and parts of the North Atlantic Ocean [72].

\subsection{Global Warming in the Ecological Systems}

In terrestrial ecosystems, the earlier timing of spring events, and poleward and upward shifts in plant and animal ranges, had been linked with high certainty to recent warming [8]. Subsequent climate change is expected to particularly affect certain ecosystems, including tundra, mangroves, and coral reefs [8]. It is expected that most ecosystems will be affected by higher atmospheric $\mathrm{CO}_{2}$ levels, combined with higher global temperatures [73]. Overall, it is expected that climate change will result in the extinction of many species and reduced diversity of ecosystems [74]. Future warming of around $3{ }^{\circ} \mathrm{C}$ (by 2100 , relative to $1990-2000$ ) could result in increased crop yields in mid- and high-latitude areas, but in low-latitude areas, yields could decline, increasing the risk of malnutrition [74]. A similar regional pattern of net benefits and costs could occur for economic effects [74]. Warming above $3{ }^{\circ} \mathrm{C}$ could result in crop yields falling in temperate regions, leading to a reduction in global food production [74].

Beginning from 1979, land temperatures have increased about twofold as fast as ocean temperatures $\left(0.25^{\circ} \mathrm{C}\right.$ per decade against $0.13{ }^{\circ} \mathrm{C}$ per decade [75]. Ocean temperatures increase more slowly than land temperatures because of the larger effective heat capacity of the oceans and because the ocean loses more heat by evaporation [76]. The Northern Hemisphere warms faster than the Southern Hemisphere because it has more land and because it has extensive areas of seasonal snow and sea-ice cover subject to ice-albedo feedback. In spite of the fact that more greenhouse gases are emitted in the Northern than Southern Hemisphere this does not contribute to the difference in warming because the major greenhouse gases persist long enough to mix between hemispheres [77]. Climate change is caused by the warming of the earth's surface and is a direct product of greenhouse gases caused by industrialization and associated economic development. Glacial melting, higher altitude melting points and changing species distribution provide evidence of climate change [6].

\subsubsection{Vector-borne Parasitoses}

It has been reviewed that the stresses triggered by climate change are likely to include population explosion leading to the spread of pests and emergence of alien species, biodiversity losses and the increase of human and animal diseases [78]. Global warming can lead to the modification of vector ecology, intensification of human-related risk factors and increase in soil, airborne and other diseases, directly related to the socioeconomic consequences of changed human behaviour. Global warming could lead to the spread of infectious diseases such as cholera, malaria, schistosomiasis and yellow fever as reviewed by Richard [78]. Anopheles mosquitoes which carry malaria are limited to areas with average temperatures of $16^{\circ} \mathrm{C}$, but with global warming; the range of these mosquitoes could be dramatically extended northwards [79] Richard. [78] has also reviewed that, further warmer temperatures accelerate the life cycles of disease-carrying insects, encouraging them to feed more often and therefore infecting significantly more people in warmer weather. A study in conducted in Rwanda found that a $1^{\circ} \mathrm{C}$ temperature rise caused malaria infections to increase by 337 percent. Extremes in climate help to create conditions that can lead to outbreaks in infectious disease [80].

In another example, the epidemic of pneumonic plaque in India in 1994 was at least partly due to hot dry conditions which enabled disease-carrying fleas to thrive. Secondly, malaria and dengue are two of the mosquito-borne diseases most likely to spread dramatically as global temperatures head upwards. Malaria (marked by chills, fever, aches and anaemia) already kills about 3,000 people, mostly children, every day. Some models project that by the end of the $21^{\text {st }}$ century, ongoing warming will have enlarged the zone of potential malaria transmission from an area containing $45 \%$ of the world's population to an area that the causative parasites are becoming resistant to standard drugs. True to the models, malaria is reappearing north and south of the tropics. The U.S. has long been home to Anopheles mosquitoes, and malaria circulated there decades ago.

Morgan and Wall [53] have stated that global climate change predictions suggest that far-ranging effects could occur in population dynamics and distributions of livestock parasites, provoking worries of widespread increases in disease incidence and production loss. However, just as development rates of many parasites of veterinary importance increase with temperature, so do their mortality rates. Temperature will also affect mortality indirectly through the action of predators, parasitoids, pathogens and competitors, whose development and abundance are also potentially temperature sensitive, so that, in the end, the net effect of climate change could be complex and far from easily predicted. 
Global climate change is actually altering the ecology of infectious agents and driving the emergence of disease in people, domestic animals, and wildlife [81]. Studies of the impact of climate warming on development rates and availability of an important parasitic nematode (Umingmakstrongylus pallikuukensis) of muskoxen in the Canadian Arctic, which is a region that is particularly vulnerable to climate change showed that warming in the Arctic may have already radically altered the transmission dynamics of this parasite, escalating infection pressure for muskoxen, and that this trend is expected to continue [82].

Climate change due to anthropogenetic activities alters both physical and biological systems globally $[21,82]$. This is seen in the shifting patterns of abundance and distribution of pathogens, including metazoan and protozoan parasites, and the emergence of infectious disease in people, livestock and wildlife, are among the most important impacts of climate change [18-23]. Dramatic consequences of climate change are already common in the Arctic region and remarkable alterations in host-parasite interactions are would be no surprise $[15,81,83,84]$. Arctic species, including ungulates and their pathogens and the invertebrate vectors, have evolved under severe seasonal and environmental constraints $[16,85]$ and the life history patterns of these species can be dramatically altered by even minor climatic fluctuations [86]. Thus, the Arctic serves as a sentinel, where studies to detect, understand and predict the responses of high latitude host-parasite systems to changing temperature can provide considerable insight into biotic implications of warming on a global scale.

Directional climate change has been altering the distribution and phenology of a variety of taxa, and is could have considerable impacts on the seasonal patterns of development and transmission of many pathogens in the Arctic and worldwide [15,16,22,84,87]. A retrospective analysis for $U$. pallikuukensis suggests that, as a result of climate warming, third larval stage development (L3) development has already shifted from a 2 year cycle to a predominantly 1 year cycle. This nonlinear shift may have great ecological significance. For the 2 year cycles characteristic of 1978-1990, high overwinter mortality of slugs and developing larvae [88] would have resulted in only a few L3 developing in the second year, and low-infection pressure for muskoxen..

Ecological disturbances associated with climate change may alter other biotic parameters that affect the epidemiology of $U$. pallikuukensis. For example, availability, survival and immunity of intermediate hosts and survival of freeliving larval stages are important determinants of parasite persistence. $D$. laeve, an important intermediate host for $U$. pallikuukensis, has high phenotypic plasticity and survives in ecologically diverse habitats under a wide range of climatic conditions $[89,90]$. It will likely thrive in a changing climate, particularly in the north, where warmer and wetter conditions are anticipated [21]. Importantly, larval stages in gastropods are buffered from the external environment because of microhabitat selection by these intermediate hosts, and consequently, survival and development rates of larvae are less likely to be impacted by climate variability and stochasticity [91] than parasites with direct life cycles. Conversely, the free-living L1 and emerged L3 may be adversely affected by extreme temperatures, desiccation, ultraviolet radiation, and frequency of freeze-thaw cycles, all possible outcomes of climate change at high latitudes [82,92,93] Climate-driven habitat perturbations are also predicted to influence habitat quantity and quality, nutrition, behaviour, immune function and patterns of geographic distribution and abundance of definitive hosts $[16,76,92]$. The final outcome for the health and persistence of muskox populations will depend on the interactions among these numerous climate-linked factors. .

Altering of the biotic and abiotic conditions by climate change will dissolve ecological barriers and redraw the maps of current distribution of parasites and their hosts $[15,16]$. The U. pallikuukensis model is a simple model for identifying and quantifying the effects of climate on critical life history stages of a nematode parasite, and explores responses of host-parasite assemblages to climate change. Such models, founded on empirical data, serve as powerful predictive frameworks for tracking of seasonal, annual and long-term changes in parasitic infections from local to global scales, and provide the foundation for developing more complex quantitative and comparative models for the epidemiology of pathogens in a changing climate.

Insect vectors of many diseases (together with the pathogens they transmit) are temperature-sensitive, for example the extrinsic incubation period of the four human species of Plasmodium varies inversely with ambient temperature. Vector-borne diseases are unusual, or rare, in cold climates. The occurrence of vector-borne disease is determined by (i) abundance of the vector, and intermediate and reservoir host(s), (ii) prevalence of disease-causing parasites (and other pathogens) suitably adapted to those vectors, the host (man or animal) and local environmental conditions such as temperature and humidity) and (iii) the resilience and behaviour of the human population, which is in dynamic equilibrium with vector-borne parasites and pathogens.

Vectors require a complicated ecosystem for their survival and reproduction. Increases in temperature and rainfall would expand habitats favourable to malaria vectors. On the other hand, increased temperature, coupled with reduced rainfall would favour new habitats for Phlebotomus sp which transmits leishmaniasis. A decreased ambient humidity would favour the transmission of lymphatic filarial. The seasonal transmission might become perennial due to an effect on vector reproduction and longevity, and vice versa [94]. Furthermore, changes in vectorial capacity might occur; rate of development of the parasite/pathogen within the vector is temperature-dependent. High altitude sites and others in northerly latitudes, such as the presently malaria-free highlands of Ethiopia, Indonesia, and Kenya [94] might become hospitable to certain vectors.

Climate particularly ambient temperature directly influences mosquito development, the gonotrophic cycle, longevity, and duration of extrinsic development of Plasmodium sp. Climate also affects other environmental factors, such as vegetation and breeding sites. In malaria-endemic areas, acquired host-immunity-is partly lost during the nontransmission season giving rise to a dramatic increase in cases during the remainder of the year [94]. Lengthening or shortening of the vector-breeding season (via climatic change) would affect the pre- valence of malaria. 
An increase of mean ambient temperature in central Africa by $2^{\circ} \mathrm{C}$ would result in the tsetse fly which transmits Trypanosoma brucei sp infection to man disappearing from the tsetse endemic middle belt of Africa southwards [94]. The tsetse fly would breed more efficiently in the forest belt where rainfall would be greater [94]. Climatic change would significantly affect the development of the parasite within the vector. These events could prove disastrous for human populations and this may even be more serious in the trypanosomiasis of domestic animals in infected areas. Other examples of vector-borne parasitoses include filariasis and leishmaniasis $[94,95]$. Global warming would extend the areas populated by the mosquito vector(s) of lymphatic filariasis; however, resultant socioeconomic factors are likely to be more important as disease-determinants worldwide [94]. The specific vector (Simulium sp) for onchocerciasis is not at present invading certain areas which are climatically suitable $[94,95]$, therefore, although minor shifts in this disease -might result from climatic change, major ones seem unlikely.

\subsubsection{Non vector-borne Parasitoses}

Soil-transmitted nematodes such as hookworms and Strongyloides stercoralis are examples of parasites which do not require a vector for transmission. Survival of eggs and larvae in moist soil is temperature dependent. Therefore these and several other soil-transmitted helminths, are likely to increase. Also, the situation would rapidly worsen in the presence of a decline in sanitation and public health standards resultant upon 'global warming.

A good number of non-vector-borne diseases are related either directly or indirectly, to the quality and quantity of the water supply. In developing countries, global warming will inevitably expand to areas where sanitation is substandard; water availability would be reduced [96]. Giardia lamblia and Entamoeba histolytica are organisms directly transmitted by infected water, or contaminated food infected by water [94]. Insufficient water-availability also favours transmission (due to inadequate hand-washing and personal hygiene). Prevalence of A. lumbricoides, Trichuris trichiura, and Enterobius vermicularis is also likely to increase.

\subsection{Depression of Human Immunity by Ultraviolet Radi- ation}

Immunity to many infectious diseases is mediated via a cellular response; this will diminish as ultraviolet (UV) radiation intensifies [86]. Exposure to summer sunlight is known to increase T-suppressor and decrease T-helper cell concentrations in peripheral blood [95]. This will influence the development and course of many infectious diseases. Otherwise mild infections in the immunosuppressed individual could become lethal [95].

\section{GLOBAL WARMING AND PARASITE DISTRIBU- TION AND BEHAVIOUR}

Global warming is affecting the world's biota and the functioning of ecosystems. Recent evidence indicates that climate change can alter the geographical distribution of parasitic diseases with possible drastic consequences on hosts. Warmer conditions can promote the transmission of parasites and raise their local abundance. Temperature-mediated changes in cercarial output varied widely among trematode species, from small reductions to 200 -fold increases in response to a $10 \mathrm{x}{ }^{\circ} \mathrm{C}$ rise in temperature, with a geometric mean suggesting an almost 8 -fold increase [30]. These results suggest that the small increases in air and water temperature forecast by many climate models will not only influence the geographical distribution of some diseases, but may also promote the proliferation of their infective stages in many ecosystems [30].

Climate affects several ecological processes, from the performance of individual organisms, to the dynamics of populations and the distribution of species. This has been clearly illustrated by a series of recent studies that have linked changes in ecosystem properties with large-scale climate fluctuations [96-99]. The extent and intensity of parasitism can be modulated by climatic conditions [100]. Recent reports have highlighted the causal relationship between climate change and emerging parasitic diseases, diseases suddenly increasing in either local prevalence or geographical distribution [70,71].

In trematodes (flukes), temperature has a very clear, and pronounced direct effect on a crucially important step of the transmission cycles. All trematodes use molluscs as first intermediate hosts. Within this host, they multiply asexually and produce relatively large numbers of infective stages known as cercariae. Typically, these free-swimming cercariae leave the snail host to penetrate their next host; the latter may be the vertebrate definitive host in which the worms mature, as in schistosomes, or a second intermediate host in which the cercariae encyst and await ingestion by the definitive host. The production of cercariae in snails is an important determinant in its transmission success. This process is also greatly dependent on temperature and it has been aptly stated that within the range of temperatures in which host and parasite can live, an increase in temperature is almost invariably coupled with an increase in cercarial output [29,101-103].

Higher temperatures will both trigger the emergence of cercariae from snails and accelerate the production of cercariae within snails [104]. The net outcome of increasing temperature will thus be a greater number of cercarial infective stages in aquatic habitats. This consequence of climate warming thus severe since trematode parasitism is not only a major veterinary and health problem worldwide, but trematodes also play major roles in the structuring of animal communities $[105,106]$.

Generally, temperatures are higher, on average, and less variable temporally, both daily and seasonally, at low latitudes than at high latitudes. At high latitudes, temperatures would often be too low to allow cercarial production.

Vicki and Barber [107] reported a dramatic effect of increased environmental temperatures on the growth rates of parasites in fish hosts. Behavioural changes in infected fish were documented suggesting that the parasites manipulate host behaviour to make them seek out warmer temperatures, creating a positive feedback mechanism to exacerbate the effects of global warming. The results provide some evidence that increasing environmental temperatures can lead to 
a shift in the delicate balance that exists between co-evolved hosts and parasites, increasing the speed with which parasites complete their life cycles and that could lead to an increase in the overall level of parasitism in natural animal populations [107]. Parasitic worms infecting fish have a devastating effect on fish reproduction and grow four times faster at higher temperatures, a fact which provides some of the initial evidence that global warming affects the interactions between parasites and their hosts [107].

Increased ranges of temperature and changes in levels of precipitation are both aspects of climate change that may affect the rate of vector-borne diseases such as malaria [6]. Lengthened seasons of transmission will make contraction of vector-borne diseases possible for longer periods of time, leading to higher rates of infection [25]. Furthermore, it has been postulated that areas of transmission could expand and therefore provide the vector with the ability to move to locations of higher altitude [25]. In the last ten years, figures of malaria have increased and this is partly blamed to climate change [108]. It has also been estimated that a one-degree increase in temperature globally could increase the number of deaths associated with malaria to 64,475 with a global burden cost of US\$2.375 million [80]. The most common victims include China, central Asia, East Africa and southern areas of South America [25].

Morgan and Wall [53] had stated that global climate change predictions suggest that far-ranging effects might occur in population dynamics and distributions of livestock parasites, provoking fears of widespread increases in disease incidence and production loss. However, they said that there is a consolation in that just as development rates of many parasites of veterinary importance increase with temperature, so do their mortality rates. Temperature, they argue could also affect mortality indirectly through the action of predators, parasitoids, pathogens and competitors, whose development and abundance are also potentially temperature dependent, so that, in the end, "the net effect of climate change could be complex and far from easily predicted.

\section{CONTROL/RECOMMENDATIONS}

The reduction of the amount of future climate change termed as mitigation of climate change is very necessary. The IPCC has defined mitigation as activities that reduce greenhouse gas (GHG) emissions, or enhance the capacity of carbon sinks to absorb GHGs from the atmosphere [72]. Many countries, both developing and developed, are aiming to use cleaner and less polluting technologies as a way of reducing $\mathrm{CO}_{2}$ emissions [109]. For great success to be achieved the policies to be adopted should include targets for emissions reduction, increased use of renewable energy, and increased energy efficiency. Since even in the most optimistic scenario, fossil fuels are going to be used for years to come, mitigation may also involve carbon capture and storage, a process that traps $\mathrm{CO}_{2}$ produced by factories and gas or coal power stations and then stores it, usually underground [110].

Adaptation to climate change may be planned, either in reaction to or anticipation of climate change, or spontaneous, being without government intervention [111]. The ability to adapt is closely linked to social and economic development
[8]. However, even societies with high capacities to adapt are still vulnerable to climate change. Planned adaptation is already occurring even though on a limited basis.

Most countries are parties to the United Nations Framework Convention on Climate Change [112], whose ultimate objective is to prevent "dangerous" anthropogenic climate change. Parties to the UNFCCC have adopted a range of policies designed to reduce greenhouse gas emissions $[13,112]$ and to assist in adaptation to global warming $[13,102]$. Parties to the UNFCCC have agreed that deep cuts in emissions are required [112] and that future global warming should be limited to below $2.0{ }^{\circ} \mathrm{C}$ relative to the preindustrial level [112]. A 2011 report of analyses by the United Nations Environment Programme [112] and International Energy Agency suggest that efforts as of the early 21 st century to reduce emissions may be inadequately stringent to meet the UNFCCC's $2{ }^{\circ} \mathrm{C}$ target.

Summarily, the practical measures of combating climate change will include (i) Working with communities to reduce their vulnerability to the disasters made worse and more numerous by climate change, and to help them adapt to the longer term challenges which a changing climate pose. (ii) Working with other organisations to share our learning of what works well and what can be done to make programmes of work with poor communities even more effective. (iii) Working with national and international bodies around the world to create and strengthen policies which reduce emissions and encourage funding and focus on adaptation to climate change. (iv). Working with schools and teachers to encourage the delivery of effective, exciting climate change lessons which engage today's young people in the issues of climate change, creating a generation of global citizens who understand the impact of their actions on the environment and people around the world. (v) Launching and supporting campaigns designed to raise awareness of the impacts of climate change on vulnerable communities, and enabling them to take tangible action to support strong and urgent change at the local, national and international level.

Control of malaria is absolutely necessary because more than one million deaths occur throughout the world due to the disease. The World Health Organisation has launched the Roll Back Malaria program which seeks to provide effective prevention and treatment of malaria in vulnerable areas. Through these initiatives, access to health care and the response to malaria can be improved in countries with poor health systems. Also, through education and awareness of the effects of climate change, individuals and societies can cooperate to reduce the threat of global warming, preventing the possibility of malaria becoming an even larger problem in the modern world [25].

Some of the strategies for controlling diseases have been outlined [53] and include (i) Draining wetlands to reduce populations of insects and other vectors, (ii) The application of insecticides and/or insect repellants to strategic surfaces such as clothing, skin, buildings, insect habitats, and bed nets. (iii) The use of a mosquito net over a bed (also known as a "bed net") to reduce night time transmission, since certain species of tropical mosquitoes feed mainly at night. (iv)The use of water wells, and/or water filtration, water fil- 
ters, or water treatment with water tablets to produce drinking water free of parasites.

(v) Development and use of vaccines to promote disease immunity. (vi) Pharmacologic pre-exposure prophylaxis (to prevent disease before exposure to the environment and/or vector).

(vii) Pharmacologic post-exposure prophylaxis (to prevent disease after exposure to the environment and/or vector). (viii) Pharmacologic treatment (to treat disease after infection or infestation). (ix) Assisting with economic development in endemic regions such as providing microloans to enable investments in more efficient and productive agriculture. (x) Climate change should be prioritized by the media as a critical concern, that is public awareness should be made using the media. It would also be needful to implement the following measures: health education on an international scale", clean and more efficient energy supplies, reduction in carbon dioxide and other greenhouse emissions, maintenance of species diversity, preservation of rain forests, abandonment of non biodegradable materials, strict regulation of toxic pollution, and widespread sustainable agriculture practice.

Global warming-induced changes are underway and scientists expect additional effects on human society and natural environments around the world. Sad still the warming is advancing due to continuous emissions. Global warming will only be slowed or arrested by implementing measures that would lead to severe cuts in emissions. Some policies to reduce emissions have been introduced but global emissions are still expected to continue to grow over time [8]. The alterations in the epidemiology of parasitic/entomological diseases are bound to remain a reality as far as global warming is not mitigated.

\section{CONFLICT OF INTEREST}

The authors have no conflict of interest with any organizations or entities listed above.

\section{ACKNOWLEDGEMENTS}

None declared.

\section{REFERENCES}

[1] Barker IK, Lindsay LR. Lyme borreliosis in Ontario: determining the risks. Can Med Assoc J 2000; 162: 1573-4.

[2] Hales S, de Wet N, Maindonald J, Woodward A. Potential effect of population and climate changes on global distribution of dengue fever: an empirical model. Lancet 2002; 360: 830-4.

[3] Gubler DJ, Reiter P, Ebi KL, Yap W, Nasci R, Patz JC. Climate variability and change in the united States: potential impacts on vector- and rodent-borne diseases. Environ Health Perspect 2001; 109: 223-33.

[4] America's Climate Choices. Panel on Advancing the Science of Climate Change; National Research Council 2010. Advancing the Science of Climate Change. Washington, D.C. The National Academies Press 2010.

[5] NOAA National Weather Service. Climate change. 2007, http://www.ncdc.noaa.gov/paleo/abrupt/story2.html

[6] Sutherst RV. Global Change and Human Vulnerability to VectorBorne Diseases. Clin Microbiol Rev 2004; 1: 136-73.

[7] America's Climate Choices. Washington, D.C.: The National Academies Press. 2011. p15. http://www.nap.edu/openbook.php? record_id=12781\&page $=1$ (Accessed in April, 2012).
IPCC AR4 SYR. Pachauri RK, Reisinger A, Ed. Climate Change 2007: Synthesis Report (SYR), Contribution of Groups I, II and III to the Fourth Assessment Report (AR4) of the Intergovernmental Panel on Climate Change, Geneva, Switzerland: IPCC, 9169-1224.

[9] Joint Science Academies 'Statement'. http://nationalacademies.org/ onpi/06072005.pdf [Retrieved 9 August 2010].

[10] Environmental Research Fund (EDF). 2012, htt://www.edf.org/ climate/human-activity-cause-warming\# [Assesed in August 2012].

[11] Wikepedia. (Assessed in March 2013)

[12] Speth JG. Red Sky at Morning: America and the Crisis of the Global Environment, New Haven: Yale University Press 2004; p. 95.

[13] United Nations Framework Convention on Climate Change (UNFCCC) (PDF), Sixth compilation and synthesis of initial national communications from Parties not included in Annex I to the Convention. Note by the secretariat. Executive summary., Geneva (Switzerland): United Nations Office at Geneva. 2005, http://unfccc.int/resource/docs/2005/sbi/eng/18.pdf [Assessed in March 2012].

[14] United Nations Climate Change conference". United Nations. Archived from the original on 20 August 2007. http://unfcc.int/ meetings/cop_13/items/4049.php. Retrieved 2007-08-03).United Nations Framework Convention on Climate Change (UNFCCC). 2011. Status of Ratification of the Convention, UNFCCC Secretariat: Bonn, Germany: UNFCCC, http://unfecc.int/ essential_background/convention/status_of_ratification/items/ 2631.php [Assessed in April 2012]

[15] Dobson A, Kutz S, Pascal M, Winfree R. Pathogens and parasites in a changing climate. In: Hannah L and Lovejoy T, Eds. Climate change and biodiversity: synergistic impacts. Advances in applied biodiversity science. Center for Applied Biodiversity Science, Conservation International Washington, DC 2003; 4: 33-38.

[16] Hoberg EP. Coevolution and biogeography among Nematodirinae (Nematoda: Trichostrongylina) Lagomorpha and Artiodactyla (Mammalia): exploring determinants of history and structure for the northern fauna across the Holarctic. J Parasitol 2005; 91: 35869.

[17] Christopher J. Is global warming nurturing parasites? Science Magazine 2002. <http://www.npr.org> on 05/05/12 from http://www.npr.org [Accessed in May 2012].

[18] Epstein PR. Climate, ecology and human health. In Consequences, Eddy JA, Ed. University Center, MI: Saginaw Valley State University 1997; Vol. 3, No. 2.

[19] Daszak P. Emerging infectious diseases of wildlife-threats to biodiversity and human health. Science 2000; 287: 443-9.

[20] Kovats RS, Campbell-Lendrum DH, McMichael AJ, Woodward A, Cox J St H. Early effects of climate change: Do they include changes in vector-borne disease? Philos Trans R Soc Lond 2001; 3560: 1057-68

[21] McCarthy JJ, Canziani OF, Leary NA, Dokken DJ, White KS Climate change: impacts, adaptation, and vulnerability. In: Cambridge University Press Contribution of Working Group II to the Third Assessment Report of the Intergovernmental Panel on Climate Change Cambridge, UK: Cambridge University Press 2001.

[22] Parmesan C, Yohe G. A globally coherent fingerprint of climate change impacts across natural systems. Nature 2003; 421: 37-42.

[23] Root TL, Price JT, Hall KR, Schneider SH, Rosenzweig C, Pounds JA. Fingerprints of global warming on wild animals and plants. Nature 2003; 421: 57-60.

[24] Kumar and Clark. Clinical Medicine. Toronto: WB Saunders 2002; p. 98 .

[25] World Health Organisation. Malaria Fact sheet No 94 May 2007.

[26] Mitchell SE, Halves J, Lampert W. Coexistence of similar genotypes of Daphnia magna in intermittent populations: response to thermal stress. Oikos 2004; 106: 469-78.

[27] Day JF, Curtis GA. Influence of rainfall on Culex nigripalpus (Diptera: Culicidae) blood-feeding behavior in Indian River County, Florida. Ann Entomol Soc Am 1989; 82: 32-7.

[28] Mouritsen K N. The Hydrobia ulvae - Maritrema subdolum association: influence of temperature, salinity, light, water-pressure and secondary host exudates on cercarial emergence and longevity. J Helminthol 2002; 76: 341-7. 
[29] Poulin R. Global warming and temperature-mediated increases in cercarial emergence in trematode parasites. Parasitology 2005; 132: $143-51$.

[30] Rose JB. Environmental ecology of Cryptosporidium and public health implications. Ann Rev Public Health 1997; 18: 135-61.

[31] Clark DP. New insights into human cryptosporidiosis. Clin Microbiol Rev 1999; 12: 554-63.

[32] Guerrant RL. Cryptosporidiosis: an emerging infection, an emerging highly infectious threat. Emeg Infect Dis 1997; 3: 51-7.

[33] Shahid NS, Rahman, AS, Sanyal SC. Cryptosporidium as a pathogen for diarrhoea in Bangladesh. Am J Trop Geogrl Med 1987; 39: 265-70

[34] Nath G, Choudhury A, Shukla BN, Singh TB, Reddy DC. Significance of Cryptosporidium in acute diarrhea in North-Eastern India. J Med Microbiol 1999; 48: 523-6.

[35] Bern C, Hernandez B, Lopez MB, Arrowood MJ, de Mérida AM, Klein RE. The contrasting epidemiology of Cyclospora and Cryptosporidium among outpatients in Guatemala. Am J Trop Med Hyg 2000; 63: 231-5.

[36] Hall SR, Tessier AJ, Duffy MG, Huebner M, Caceres CE. Warmer does not have to mean sicker: temperature and predators can jointly drive timing of epidemics. Ecology 2006; 87: 1684-95.

[37] Stacey DA, Thomas MB, Blanford S, Pell JK, Pugh C, Fellowes $\mathrm{MD}$. Genotype and temperature influence pea aphid resistance to a fungal entomopathogen. Physiol Entomol 2003; 28: 75-81.

[38] Carruthers RI, Larkin TS, Firstencel H, Feng Z. Influences of thermal ecology on the mycosis of a rangeland grasshopper. Ecology 1992; 73: 190-204.

[39] Blanford S, Thomas MB. Host thermal biology: the key to understanding host-pathogen interactions and microbial pest control? Agric Forest Entomol 1999; 1: 195-202.

[40] Blanford S, Thomas MB, Pugh C, Pell JK. Temperature checks the Red Queen: Resistance and virulence in a fluctuating environment. Ecol Lett 2003; 6: 2-5.

[41] Huey RB, Hertz, PE. Is a jack-of-all-temperatures a master of none? Evolution 1984; 38: 441-4.

[42] Huey RB, Kingsolver JG. Evolution of thermal sensitivity of ectotherm performance. Trends Ecol Evol 1989; 4: 131-5.

[43] Huey RB, Kingsolver JG. Evolution of resistance to high temperature in ectotherms. Am Nat 1993; 142: 21-46.

[44] Thomas MB, Blanford S. Thermal biology in insect-parasite interactions. Trends Ecol Evol 2003; 18: 344-350.

[45] Hudson PJ, Dobson AP, Newborn D. Do parasites make prey vulnerable to predation? Red Grouse and parasites. J Anim Ecol 1992; 61: 681-92.

[46] Packer C, Holt RD, Hudson PJ, Lafferty KD, Dobson AP. Keeping the herds healthy and alert: implications of predator control for infectious disease. Ecol Lett 2003; 6: 797-802.

[47] Lafferty KD. Fishing for lobsters indirectly increases epidemics in sea urchins. Ecol Appl 2004; 14: 1566-73.

[48] Ostfeld RS, Holt RD. Are predators good for your health? Evaluating evidence for top-down regulation of zoonotic disease reservoirs. Front Ecol Environ 2004; 2: 13-20.

[49] Duffey MA, Hall SR, Tessier AJ, Huebner M. Selective predators and their parasitized prey: top-down control of epidemics. Limnol Oceanogr 2005; 50: 412-20.

[50] Hall SR, Duffy, MA, Caceres CE. Selective predation and productivity jointly drive complex behaviour in host-parasite systems. Am Nat 2005; 180: 70-81.

[51] Morgan ER, Wall R. Climate change and parasitic disease: farmer mitigation? Trends Parasitol 2009; 25: 308-13.

[52] Wall R, Ellse LS. Climate change and livestock parasites: integrated management of sheep blowfly strike in a warmer environment. Glob Change Biol 2011; 17: 1770-7.

[53] Neboja, Rob S, Eds. IPCC. Cambridge University Press: UK 2000; p. 570 .

[54] Weart S. "The Carbon Dioxide Greenhouse Effect". The Discovery of Global Warming. American Institute of Physics. http://www.aip. org/history/climate/co2.htm. 2008. [Assessed in April 2009].

[55] Le Treut T. FAQ 1.1, AR4 WG1 2007. http://www.ch/publications and_data/ ar4/wg1/en/ch1.html, p. 97. [Assessed in March 2012].

[56] Kiehl JT, Trenberth KE. Earth's annual global mean energy budget. Bull Am Meteor Soc 1997; 78: 197-208.
[57]

Schmidt G. "Water vapour: feedback or forcing?". Real Climate. 2005, http://www.realclimate.org/index.php?p=142. [Retrieved 21 April 2009].

[58] Russell R. The Greenhouse Effect \& Greenhouse Gases University Corporation for atmospheric research windows to the Universe. 2007. Http://www.windows.ucar.edu/tour/link=/earth/climate/greenhouse effect gases.html\&edu=high 2007. [Assessed in December 2009].

[59] EPA. Recent Climate Change: Atmosphere Changes. Climate Change Science Program. United States Environmental Protection Agency. 2007, http://www.epa.gov/climatechange/ science/recentac.html. [Retrieved 21 April 2009].

[60] Spahni R. Atmospheric methane and nitrous oxide of the late pleistocene from Antarctic ice cores. Science 2005; 310: 1317-21.

[61] Pearson PN, Palmer MR. Atmospheric carbon dioxide concentrations over the past 60 million years. Nature 2000; 406: 695-99.

[62] IPCC TAR WG3. Metz B, Davidson O, Swart R, Pan J, Ed. Climate Change 2001: Mitigation, Contribution of Working Group III to the Third Assessment Report of the Intergovernmental Panel on Climate Change. UK: Cambridge University Press 2001.

[63] National Research Council (NRC). Solar influences on global change. Washington, D.C.: National Academy Press 1994; p.36.

[64] Lockwood M, Fröhlich C. Recent oppositelydirected trends in solar climate forcings and the global mean surface air temperature. II. Different reconstructions of the total solar irradiance variation and dependence on response time scale. Proc R Soc 2008; 1367-85.

[65] Hansen J. Efficacy of climate forcings. J Geophys Res 2005; 110 (D18): D18104. Bibcode 2005JGRD.11018104H. doi:10.1029/ 2005JD005776.

[66] Climate Change: A Summary of the Science. Royal Society 2010. Http://royalsociety.org/WorkArea/DownloadAsset.assp ?id=4294972963 [Assessed in March 2012].

[67] USGRCP (n.d.). Key Findings. On (website): Global Climate Change. Impacts in the United States". U.S. Global Change Research Program website. http://www.globalchange.gov/publications/reports/scientific-assessments/us-impacts/key-findings [Retrieved 17 April 2010].

[68] Marcoglies DJ. Implications of climate change for parasitism of animals in the aquatic environment. Can J Zool 2001; 79: 1331-52.

[69] Harvell CD, Mitchell CE, Ward JR, Altizer S, Dobson AP, Ostfeld RS, Samuel MD. Climate warming and disease risks for terrestrial and marine biota. Science 2002; 296: 2158-62.

[70] IPCC AR4 WG3. Metz B, Davidson OR, Bosch PR, Dave R, Meyer LA, Ed. Climate Change 2007: Mitigation of Climate Change, Contribution of Working Group III to the Fourth Assessment Report of the Intergovernmental Panel on Climate Change. UK: Cambridge University Press 2007.

[71] Fischlin E. Chapter 4: Ecosystem, their properties, goods and Services, Executive Summary 2007; p. 213.

[72] Schneider S. Chapter 19: Assessing Key Vulnerabilities and the Risk from Climate Change, Section 19.3.2.1. Agriculture 2007.

[73] Trenberth E. Chapter 3, Observations: Atmospheric Surface and Climate Change, Section 3.2.2.2: Urban Heat Islands and Land Use Effects 2007; p. 244.

[74] Rowan TS, Buwen D, Jonathan MG. Land/sea warming ratio in Response to climate change: AR4 model results and comparison with observations. Geophys Res Lett 2007; 34: doi:10.1029/ 2006GL028164. http://www.agu.org/pubs/crossref/2007/2006GL028164.shtml. [Retrieved 19 September 2007].

[75] Ehhalt E. Chapter 4: Atmospheric Chemistry and Greenhouse Gases Section 4.2.3.1: Carbon monoxide $(\mathrm{CO})$ and hydrogen $\left(\mathrm{H}_{2}\right)$ 2001; p. 256.

[76] Richard S. If mercury soars, so may health hazards. Science 1995; 267: 957-8.

[77] Martin PH, Lefebvre MG. Malaria and climate: sensitivity of malaria potential transmission to climate. Ambio 1995; 24: 200-7.

[78] Bosello F, Roberto R, Richard SJ. Economy-wide estimates of the implications of climate-change: human health. Ecol Econ 2006; 58 : 579-91.

[79] Kutz SJ, EP Hoberg, JS Nishi, L Polley. Development of the muskox lungworm, Umingmakstrongylus pallikuukensis (Protostrongylidae) in gastropods in the Arctic. Can J Zool 2002; 81: 1977-85.

[80] Hassol SJ. Impacts of a warming arctic, arctic climate impact assessment. In: Cambridge University Press New York: Cambridge University Press 2004 
[81] Hoberg EP, Kutz, SJ, Galbreath, KE, Cook J. Arctic biodiversity: From discovery to faunal baselines- revealing the history of a dynamic ecosystem. J Parasitol 2003; 89: 84-95.

[82] Kutz SJ, Garde E, Veitch A, Nagy J, Ghandi F, Polley L. Muskox lungworm (Umingmakstrongylus pallikuukensis) does not establish in thinhorn sheep (Ovis dalli). J Wildl Dis 2004; 40: 197-204.

[83] Strathdee AD, Bale JS. Life on the edge: insect ecology in arctic environments. Annu Rev Entomol 1998; 43: 85-106.

[84] Graham RW. Spatial response of mammals to late quaternary environmental fluctuations. Science 1996; 272: 1601-6.

[85] Harvell CD, Mitchell CE, Ward JR, et al. Climate warming and disease risks for terrestrial and marine biota. Science 2002; 296: 2158-62.

[86] Pilsbry HA. Land mollusca of North America. In Monograph 3 1948 Philadelphia: Academy of Natural Science 1948; pp. 539-52.

[87] Rollo CD, Shibata DM. Resilience, robustness, plasticity in a terrestrial slug,with particular reference to food quality. Can J Zool 1991; 69: 978-87.

[88] Saunders LM, Tompkins DM, Hudson PJ. Stochasticity accelerates nematode egg development. J Parasitol 2002; 88: 1271-2.

[89] Forrester DJ, Senger CM. Effect of temperature and humidity on survival of first stage Protostrongylus stilesi larvae. Exp Parasitol 1963; 13: 83-9.

[90] Shostak A, Samuel WM. Moisture and temperature effects on survival and infectivity of first-stage larvae of Parelaphostrongylus odocoileiand P. tenuis (Nematoda: Metastrongyloidea). J Parasitol 1984; 70: 261-9.

[91] Shostak A, Samuel WM. Moisture and temperature effects on survival and infectivity of first-stage larvae of Parelaphostrongylus odocoileiand P. tenuis (Nematoda: Metastrongyloidea). J Parasitol 1984; 7: 261-9.

[92] World Health Organization. Potential health effects of climatic change. Geneva: WHO, 1990; pp58.

[93] McCally M, Cassel CK. Medical responsibility and global environmental change. Ann Intern Med 1990; 113: 467-73.

[94] Cook GC. The impact of global environmental change on human disease patterns. THS Health Summary 1991; 8: 7-8.

[95] Ottersen G, Planque B, Belgrano A, Post E, Reid PC, Stenseth NC. Ecological effects of the North Atlantic Oscillation. Ecologia 2001; 128: $1-14$

[96] Stenseth NC, Mysterud A, Ottersen G, Hurrell JW, Chan KS, Lima M. Ecological effects of climate fluctuations. Science 2002; 297: 1292-6.

[97] Walther GR, Poste E, Convey P, et al. Ecological responses to recent climate change. Nature 2002; 416: 389-95.

[98] Mouritsen KN, Poulin R. Parasitism, climate oscillations and the structure of natural communities. Oikos 2002a; 97: 462-8.
[99] Shostak AW, Esch GW. Photocycle dependent emergence by cercariae of Halipegus occidualis from Helisoma anceps, with special reference to cercarial emergence patterns as adaptations for transmission. J Parasitol 1990; 76: 790-5.

[100] Lo C-T, Lee K.-M. Pattern of emergence and the effects of temperature and light on the emergence and survival of heterophyid cercariae (Centrocestus formosanus and Haplorchis pumilio). J Parasitol 1996; 82: 347-50.

[101] Umadevi K, Madhavi R. Effects of light and temperature on the emergence of Haplorchis pumilio cercariae from the snail host, Thiara tuberculata. Acta Parasitol 1997; 42: 12-16.

[102] Ataev GL. Temperature influence on the development and biology of ediae and cercariae of Philophthalmus rhionica (Trematoda). Parazitologiya 1991; 25: 349-59.

[103] Sousa WP. Can models of soft-sediment community structure be complete without parasites? Am Zool 1991; 31: 821-30.

[104] Mouritsen KN, Poulin R. Parasitism, community structure and biodiversity in intertidal ecosystems. Parasitology 2002b; 124: 10117.

[105] Vicki M, Iain B. Some (worms) like it hot: fish parasites grow faster in warmer water, and alter host thermal preferences Global Change Biol 2011; DOI: 10.1111/j.1365-2486.2011.02595.x

[106] Tanser CF, Sharp B, Le Sueur D. Potential effect of climate change on malaria in Africa. Lancet 2003; 362: 1792-98.

[107] World Bank. World Development Report 2010: Development and World Development Report 2010: Development and Climate Change. The International Bank for Reconstruction and Development / The World Bank, 1818 H Street NW, Washington DC 20433. doi:10.1596/978-0-8213-7987-5.

[108] Robinson S. How to reduce Carbon emissions: Capture and Store? 2010 Time. http://www.time.com/ time/specials /packages/ article/0,28804,1954176_1954175,00.html. [Retrieved 9 August 2010].

[109] Smit E. Chapter 18: Adaptation to Climate Change in the Context of Sustainable Development and Equity, Section 18:2.3. Adaptation Types and Forms 2001.

[110] United Nations Framework Convention on Climate Change (UNFCCC). Compilation and synthesis of fifth national communications. Executive summary. Note by the secretariat. Geneva (Switzerland): United Nations Office at Geneva 2011; http://unfccc.int/resource/ docs/2011/sbi/eng/inf01.pdf

[111] United Nations Environment Programme (UNEP). "Executive Summary" (PDF), Bridging the Emissions Gap: A UNEP Synthesis Report. Nairobi, Kenya: UNEP 2011; p.8.

[112] International Energy Agency (IEA). Executive summary (English), World Energy Outlook. Paris, France: IEA 2011; p. 2.

(C) Atehmengo et al.; Licensee Bentham Open.

This is an open access article distributed under the terms of the Creative Commons Attribution License (http://creativecommons.org/licenses/by/2.5/), which permits unrestrictive use, distribution, and reproduction in any medium, provided the original work is properly cited. 